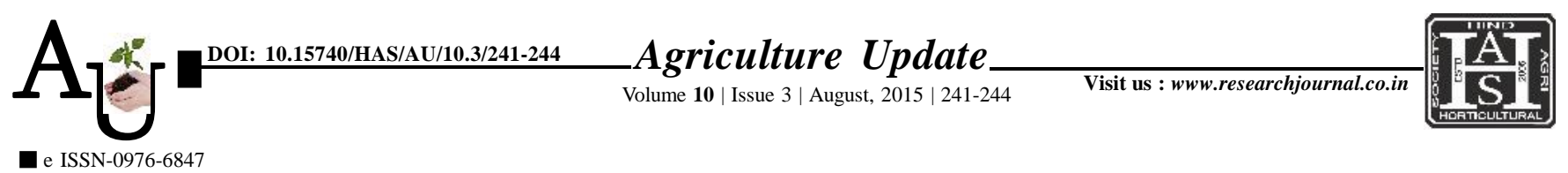

\title{
Research Article: Knowledge of orange root stock by orange nursery growers
}

\section{S.P. KHARPE, S.U. MOKHALE AND N.O. KHANDARE}

Article Chronicle: Received :

24.06.2015;

Revised :

19.07.2015;

Accepted :

15.08.2015

KeY WORDS:

Knowledge, Orange root stock, Orange nursery grower, Rangur lime, Jamberi
SUMMARY : The present investigation was conducted in Warud Panchayat Samiti of Amravati district in Maharashtra state. The main objective of the study was to assess the relationship between selected characteristic of orange nursery growers about orange root stock. A pre-structured interview schedule was used to collect data from 100 orange nursery growers from 5 villages which were selected by proportionate random sampling. The statistical methods such as frequencies, percentage, mean, standard deviation, correlation and multiple regression analysis were used. The data of research study show that age was negatively correlated and education, land holding, extension contact, area under orange nursery cultivation and social participation were from found to be positively and significantly related with knowledge of orange root stock. Multiple regression analysis indicated that from all selected nine variables, four variables namely education, annual income, area under orange nursery cultivation and extension contact were significantly contributing factors in case of knowledge of orange root stock by nursery growers.

How to cite this article : Kharpe, S.P., Mokhale, S.U. and Khandare, N.O. (2015). Knowledge of orange root stock by orange nursery growers. Agric. Update, 10(3): 241-244.
Author for correspondence :

\section{S.U. MOKHALE}

Department of

Extension Education, Shri Shivaji Agriculture College, AMRAVATI (M.S.) INDIA

See end of the article for authors' affiliations 